ISSN 1392-3196 / e-ISSN 2335-8947

Zemdirbyste-Agriculture, vol. 103, No. 4 (2016), p. 363-368

DOI 10.13080/z-a.2016.103.046

\title{
Microdochium nivale and M. majus as causative agents of seedling blight in spring cereals
}

\author{
Akvilė JONAVIČIENĖ, Skaidrė SUPRONIENĖ, Roma SEMAŠKIENĖ \\ Institute of Agriculture, Lithuanian Research Centre for Agriculture and Forestry \\ Instituto 1, Akademija, Kèdainiai distr., Lithuania \\ E-mail: akvile@1zi.lt
}

\begin{abstract}
Seedling blight, mostly caused by Fusarium spp. and Bipolaris sorokiniana, is a common disease in spring cereals. This research confirmed the presence of Microdochium fungi in a complex of seedling blight causative agents. Pathogens Microdochium nivale and M. majus in the seed and in stem base of seedlings of spring barley, spring wheat, spring triticale and spring oats were identified and quantified using a quantitative real-time polymerase chain reaction (qPCR) in 2013-2015. Both species were detected in the seed of all spring cereals tested. The amount of M. nivale and M. majus DNA was the highest in seeds of barley. Both Microdochium pathogens were present in the stem base of seedlings of all spring cereals tested; however, a high variation between cereal species and years was established. In most cases, the quantity of $M$. nivale DNA was the lowest in the seedlings of oats, while that of M. majus - in the seedlings of barley compared to the other cereal species tested. Higher contents of M. majus and $M$. nivale DNA were identified in the stem base of the seedlings emerged from untreated seeds compared with the seedlings emerged from the fludioxonil-treated seeds. However, the effect of tebuconazole on the reduction of M. nivale and M. majus DNA was inconsistent. Our findings suggest that M. nivale and M. majus occur in the seed of spring cereals and cause seedling blight, therefore research on these pathogens needs to be extended.
\end{abstract}

Key words: fludioxonil, Microdochium majus, M. nivale, seed infection, seedling blight, tebuconazole.

\section{Introduction}

Formerly Microdochium (syn. Lanosa navalis (Fr.), Fusarium nivale (Fr.)) were initially identified as Fusarium species on the morphological basis (Wollenweber, Reinking, 1935), but later studies differentiated the genus Microdochium from Fusarium (Samuels, Hallett, 1983). Glynn et al. (2005) described M. nivale and M. majus as separate species: Microdochium nivale (Fr.) Samuels \& I.C. Hallett and Microdochium majus (Wollenw.) Glynn \& S.G. Edwards. Both pathogens are important nontoxigenic fungal pathogens of many cereal crops causing seedling blight, foot rot and also belong to the Fusarium head blight fungal complex (Amein et al., 2007; Walker et al., 2009; Nielsen et al., 2011; Jørgensen et al., 2012). Microdochium fungi are associated with retardation of seed germination (Hudec, Muchova, 2010) and significant yield losses (Humphreys et al., 1995; Amein et al., 2007).

$M$. nivale causes seedling blight and brown foot rot and tend to occur under cooler conditions and have trivial meaning in warmer localities (Doohan et al., 2003; Roháčik, Hudec, 2005). Brown foot rot on winter wheat stem base is present in significant amounts with $M$. nivale and M. majus (Bateman et al., 2000). M. nivale was more common on winter barley than on winter wheat (Dawson, Bateman, 2001). In another study winter wheat was more susceptible to Fusarium species and M. nivale than winter barley (Hudec, 2007). Usually Microdochium species is present as one or both (Nicholson et al., 2002). The Ren et al. (2015) study established that $M$. nivale was a more aggressive Fusarium seedling blight pathogen causing $30 \%$ higher disease severity on wheats than M. majus. According to Matusinsky et al. (2008), M. nivale was found on the stem base most frequently on winter wheat and the statistical association was confirmed between $M$. nivale and M. majus. Out of these, M. nivale tended to decrease in the summer season.

$M$. nivale (Fusarium nivale) was identified on winter wheat and rye stem base and M. majus was found on rye in 1970 in Lithuania (Špokauskienè, 1991), but there is no information about Microdochium spp. causal agent on stem base of spring cereals. Cockerell et al. (2009), based on the limited data sets in Scotland, suggested that spring wheat and oats are at risk from high levels of Microdochium infection, and spring barley is also at risk but at levels exceeding 30\% seed infection. It is known that Microdochium affects seedlings at temperatures as low as $3^{\circ} \mathrm{C}$ (Haigh et al., 2009). In an inoculation experiment at $10^{\circ} \mathrm{C}$, Simpson et al. (2000) found that both Microdochium species were pathogenic to wheat and rye but only $M$. nivale caused significant disease in oats. These studies showed that Microdochium species can be important pathogens in spring cereals also. $M$. nivale and $M$. majus as seedling blight pathogens in spring cereals in Lithuania have not been described before. The present study was undertaken to determine whether $M$. nivale and $M$. majus affect seed and stem 
base of spring cereals and estimate the susceptibility of different spring cereal species to both pathogens.

\section{Materials and methods}

Field experiment. Field experiments involving spring barley cv. 'NFC Tipple', spring wheat cv. 'Tybalt', spring triticale cv. 'Nilex' and spring oats cv. 'Vendela' were carried out at Institute of Agriculture, Lithuanian Research Centre for Agriculture and Forestry during 2013-2015. Experiments were set up in three treatments using untreated seeds, fludioxonil $\left(25 \mathrm{~g} \mathrm{l}^{-1}\right.$, commercial product Maxim $025 \mathrm{FS}$ (Syngenta))-treated seeds at a dose of $2.0 \mathrm{l} \mathrm{t}^{-1}$ and tebuconazole $\left(60 \mathrm{~g} \mathrm{l}^{-1}\right.$, commercial product Chambel 6 FS (Makhteshim Chemical Works Ltd.)) at a dose of $0.51 \mathrm{t}^{-1}$. Seeds were treated using a liquid seed dresser Hege 11 (Wintersteiger, Austria). The experiments were laid out in a randomized complete block design in four replications with $15 \mathrm{~m}^{2}$ plot size. In all experimental years, cereals were pre-crops.

Sampling and DNA extraction. Before sowing, a seed sample of $10 \mathrm{~g}$ per species was taken from naturally infected seeds and homogenized with a mixer mill MM400 (Retsch, Germany). Thirty plants (BBCH 13) with disease symptoms were collected from each treatment from three replications and $1 \mathrm{~cm}$ long stem base segments were powdered in liquid nitrogen. A total of $100 \mathrm{mg}$ per each seed and plant sample were taken for the DNA extraction with a NucleoSpin Plant II (Machery-Nagel, Germany) according to the manufacturer's instructions.

Quantitative real-time polymerase chain reaction ( $q P C R$ ) analysis. $\mathrm{qPCR}$ was done according to the protocol of Nielsen et al. (2013) with the following modifications: total volume of $15 \mu \mathrm{l}$ consisting of 7.5 $\mu 1$ Power SYBR Green PCR Master Mix (Applied Biosystems, USA), $300 \mathrm{nM}$ of each primer, $0.5 \mu \mathrm{g} \mu \mathrm{l}^{-1}$ BSA (Thermo Fisher Scientific, Lithuania) and $2.5 \mu \mathrm{l}$ template DNA. Genomic DNA extracted from seeds and plant stem bases was diluted 1:20 and PCR reactions were performed in duplicate on all samples. PCR was run in a 7900HT Fast Real-time PCR System (Applied Biosystems, USA) using Nielsen et al. (2013) cycling protocol. A list of specific primers used is provided in Table 1.

Table 1. A list of sequences and species specific primers used for analysis

\begin{tabular}{|c|c|c|c|}
\hline Species detected & Primer & Sequence $\left(5^{\prime}-3^{\prime}\right)$ & Source \\
\hline Microdochium nivale & $\begin{array}{l}\text { Mniv1f } \\
\text { Mniv1r }\end{array}$ & $\begin{array}{l}\text { TTGGCTTGCACAAACAATACTTTTT } \\
\text { AGCACAACAGGCGTGGATAAG }\end{array}$ & Nielsen et al., 2013 \\
\hline Microdochium majus & $\begin{array}{l}\text { Mmajus1f } \\
\text { Mmajus1r }\end{array}$ & $\begin{array}{l}\text { AACCCCTCCCGGGTCAG } \\
\text { GGATAAACGACACTTGAAGACAGAAAA }\end{array}$ & Nielsen et al., 2013 \\
\hline Plant EF $1 \alpha$ & $\begin{array}{l}\text { Hor1f } \\
\text { Hor2r }\end{array}$ & $\begin{array}{l}\text { TCTCTGGGTTTGAGGGTGAC } \\
\text { GGCCCTTGTACCAGTCAAGGT }\end{array}$ & Nicolaisen et al., 2009 \\
\hline
\end{tabular}

M. nivale and M. majus pure culture originated from Leibniz-Institut DSMZ, Germany. DNA concentrations and quality of fungi (obtained from pure culture) for standard curves were measured by a biophotometer (Eppendorf, Germany). Six-fold dilution sets starting from 1:10 DNA were used (Suproniene et al., 2010; Nielsen et al., 2013).

Meteorological conditions. Cool weather is favourable for Microdochium fungi (Doohan et al., 2003).
It has been noted that sowing seeds in cold soil increases seed germination time and this can lead to infection of seedlings with soil pathogens (Hwang et al., 2000). During the spring cereal growing seasons, the amount of rainfall was the highest $(52 \mathrm{~mm})$ in 2015 and the lowest (30-32 mm) in 2013 and 2014 (Table 2). Average air temperature and the average soil surface temperature during spring cereal growing season was lowest in 2014 and 2015 while highest in 2013.

Table 2. Meteorological observations

\begin{tabular}{lcccccccc}
\hline \multirow{2}{*}{\multicolumn{1}{c}{ Time }} & \multicolumn{3}{c}{\begin{tabular}{c} 
Average air temperature \\
\multicolumn{1}{c}{}
\end{tabular}} & \multicolumn{2}{c}{$\begin{array}{c}\text { Amount of rainfall } \\
\text { mm }\end{array}$} & \multicolumn{3}{c}{$\begin{array}{c}\text { Average soil surface } \\
\text { temperature }\end{array}$} \\
\cline { 2 - 8 }${ }^{\circ} \mathrm{C}$
\end{tabular}

Statistical analysis. Relationships between amounts of pathogen DNA in seeds and stem bases or seedling blight severity were determined by the correlation analyses $(P \leq 0.05)$ using $S A S$ Enterprise Guide 7.1 (SAS Institute Inc.). Standard deviation of the set of data values was calculated. Real-time PCR values are presented as the amount of fungal DNA per amount of plant DNA.

\section{Results and discussion}

Naturally infected seeds were analyzed for Microdochium nivale and M. majus presence by qPCR.
The results showed that $M$. nivale and M. majus were present in all seed samples of spring barley, spring wheat, spring triticale and spring oats (Table 3). Nielsen et al. (2011) also detected M. nivale and M. majus at significant amounts in almost all winter wheat, spring barley, oats, rye and triticale grain samples. Both fungal species were detected in all Danish cereal species, but M. majus prevailed against $M$. nivale in most years in all cereal species except rye, in which $M$. nivale represented a larger proportion of the biomass and was more prevalent than M. majus (Nielsen et al., 2013). In our experiments, $M$. nivale and $M$. majus in seeds determined equally while biomass of $M$. nivale in some cases was higher. 
Table 3. Quantity of Microdochium nivale and M. majus (fungal DNA pg per plant DNA ng) on the seed of spring cereals, expressed as mean values and standard deviation

\begin{tabular}{lccc}
\hline \multicolumn{1}{c}{ Crop } & 2013 & 2014 & 2015 \\
\hline \multicolumn{4}{c}{ M. nivale } \\
\hline Spring barley & $5.38 \pm 0.43$ & $1.86 \pm 0.32$ & $4.49 \pm 0.56$ \\
Spring wheat & $0.31 \pm 0.02$ & $0.21 \pm 0.02$ & $0.26 \pm 0.00$ \\
Spring triticale & $2.29 \pm 0.79$ & $0.07 \pm 0.00$ & $0.26 \pm 0.24$ \\
Spring oats & $1.74 \pm 0.37$ & $0.43 \pm 0.01$ & $0.94 \pm 0.39$ \\
\hline \multicolumn{5}{r}{ M. majus } \\
\hline Spring barley & $2.13 \pm 0.27$ & $0.46 \pm 0.13$ & $2.65 \pm 0.54$ \\
Spring wheat & $0.76 \pm 0.07$ & $0.02 \pm 0.01$ & $0.29 \pm 0.01$ \\
Spring triticale & $2.35 \pm 0.02$ & $0.01 \pm 0.00$ & $0.08 \pm 0.01$ \\
Spring oats & $1.35 \pm 0.57$ & $0.07 \pm 0.03$ & $0.61 \pm 0.06$ \\
\hline
\end{tabular}

M. nivale was observed in different amounts in all spring cereal seeds and investigation years. A smaller quantity of $M$. nivale DNA was identified in spring wheat seeds compared to other cereal species. According to DNA quantities in seeds, spring barley was the most susceptible to $M$. nivale. Host plant response to pathogen infection was shown in all experimental years. Our results agree with those of Nielsen et al. (2011) who found that the amounts of $M$. nivale and $M$. majus in winter wheat were generally lower than in other cereal grains.

M. majus also prevailed in spring barley seeds and higher DNA quantities were found in 2013 and 2015. The year 2014 was characterised by small quantities of both Microdochium species in the seed of spring cereals and in 2013 by large quantities. Significant interactions between cereal genotypes and fungal species have been established suggesting that resistance/tolerance mechanisms and genes may influence the disease caused by individual Microdochium species (Ren et al., 2015). Our study suggests that barley might be most susceptible to both Microdochium species compared to the other spring crops, while wheat might be most resistant; however, investigations of different genotypes are essential to get more valid results.

In the field trials, visual seedling blight incidence and severity index varied between crops and investigation years, but symptoms of the disease were observed in all investigated crops (data not shown). In all experimental years, spring oats were the least damaged by seedling blight of all the species tested. Haigh and Hare (2012) have reported that disease symptoms did not occur on seedlings grown from the non-infected seed lot in vitro and the presence of Microdochium spp. was confirmed on seedlings from the infected seed lot. In our study, all seed lots were infected with both Microdochium species and therefore we expected to detect them in diseaseaffected stem bases.

Analyses of qPCR for identification of causal pathogens in stem base of the seedlings of different spring cereals confirmed the presence of both pathogens $M$. nivale and $M$. majus (Table 4). The amount of their DNA varied between host plants and years. The quantity of $M$. nivale DNA in most cases was the lowest in the seedlings of oats, while M. majus - in barley seedlings compared to the other tested species McNeil et al. (2012) found a clear difference in host (spring barley and spring oats) preference of Microdochium species. The current study suggests the advantage of $M$. majus over $M$. nivale on spring wheat, spring triticale and spring oats, whereas spring barley was more sensitive to $M$. nivale. Simpson et al. (2000) in the mixed inoculation trial found that $M$. nivale var. majus showed a selective advantage on winter wheat and winter oats seedlings and $M$. nivale var. nivale showed a strong selective advantage on winter rye seedlings.

Table 4. The presence of Microdochium nivale and M. majus (fungal DNA pg per plant DNA $\mu \mathrm{g}$ ) in naturally infected spring cereal seedling stem bases at BBCH 13 in 2013-2015

\begin{tabular}{lcccccccc}
\hline \multirow{2}{*}{ Crop } & \multicolumn{4}{c}{ M. nivale } & \multicolumn{4}{c}{ M. majus } \\
\cline { 2 - 10 } & $\min$ & $\max$ & average & SD & $\min$ & $\max$ & average & SD \\
\hline Spring barley & 3.47 & 92.97 & 34.3 & 50.8 & 0 & 14.36 & 6.3 & 7.4 \\
Spring wheat & 0.71 & 89.27 & 30.6 & 50.8 & 9.36 & 370.20 & 132.0 & 206.3 \\
Spring triticale & 0.6 & 22.70 & 10.3 & 11.3 & 4.78 & 88.28 & 40.9 & 42.9 \\
Spring oats & 0 & 1.06 & 0.4 & 0.6 & 0.34 & 30.48 & 11.0 & 16.9 \\
\hline
\end{tabular}

$\mathrm{SD}$ - standard deviation

Stem base of seedlings from untreated seeds contained higher amount of M. majus and M. nivale DNA than seedlings from fludioxonil-treated seeds (Table 5). Glynn et al. (2008) found that M. nivale and M. majus were highly sensitive to fludioxonil. There was a significant interaction between species and fungicide, with $M$. majus being proportionally more sensitive to fludioxonil than $M$. nivale. Walker et al. (2009) also reported that fludioxonil used for seed treatments was effective against Microdochium spp. Simpson et al.
(2001) reported that tebuconazole showed little control of $M$. nivale. Other studies showed that tebuconazole has intermediate values for Microdochium fungi and no differences were found between the Microdochium species sensitivity (Walker et al., 2009). In the present study, the seed treatment fungicide fludioxonil tended to decrease the DNA amounts of both Microdochium in all crops and tested years. The other seed treatment fungicide tebuconazole showed variable results of biomass reduction of $M$. nivale and $M$. majus. 
Table 5. Amounts of Microdochium nivale and M. majus (fungal DNA pg per plant DNA $\mu \mathrm{g}$ ) in the stem bases of spring cereals at $\mathrm{BBCH} 13$, expressed as mean values and standard deviation

\begin{tabular}{|c|c|c|c|c|c|c|}
\hline \multirow{2}{*}{ Treatment } & \multicolumn{2}{|c|}{2013} & \multicolumn{2}{|c|}{2014} & \multicolumn{2}{|c|}{2015} \\
\hline & M. nivale & M. majus & M. nivale & M. majus & M. nivale & M. majus \\
\hline \multicolumn{7}{|c|}{ Spring barley } \\
\hline Untreated & $3.47 \pm 0.44$ & $4.41 \pm 0.12$ & $6.45 \pm 0.45$ & 0 & $92.97 \pm 7.56$ & $14.36 \pm 0.36$ \\
\hline Fludioxonil & $0.18 \pm 0.02$ & 0 & 0 & 0 & $1.20 \pm 0.20$ & 0 \\
\hline Tebuconazole & $1.46 \pm 0.21$ & $4.03 \pm 0.87$ & $1.75 \pm 0.18$ & 0 & $86.02 \pm 11.81$ & $2.20 \pm 0.20$ \\
\hline \multicolumn{7}{|c|}{ Spring wheat } \\
\hline Untreated & $1.90 \pm 0.61$ & $9.36 \pm 0.25$ & $2.50 \pm 0.44$ & $16.45 \pm 0.93$ & $89.27 \pm 10.73$ & $370.20 \pm 77.08$ \\
\hline Fludioxonil & $1.07 \pm 0.11$ & $0.72 \pm 0.12$ & $0.43 \pm 0.33$ & 0 & 0 & $0.71 \pm 0.01$ \\
\hline Tebuconazole & $1.21 \pm 0.06$ & $9.50 \pm 0.97$ & $0.71 \pm 0.12$ & $0.15 \pm 0.00$ & $1.29 \pm 0.29$ & $106.69 \pm 7.96$ \\
\hline \multicolumn{7}{|c|}{ Spring triticale } \\
\hline Untreated & $22.70 \pm 5.65$ & $88.28 \pm 5.18$ & $0.60 \pm 0.10$ & $29.75 \pm 0.97$ & $7.55 \pm 0.59$ & $4.78 \pm 0.55$ \\
\hline Fludioxonil & $7.47 \pm 1.04$ & $37.35 \pm 3.08$ & 0 & 0 & 0 & $0.12 \pm 0.02$ \\
\hline Tebuconazole & $14.90 \pm 3.39$ & $76.71 \pm 5.57$ & 0 & 0 & $0.42 \pm 0.02$ & $0.59 \pm 0.09$ \\
\hline \multicolumn{7}{|c|}{ Spring oats } \\
\hline Untreated & $1.06 \pm 0.06$ & $30.48 \pm 0.48$ & 0 & $0.34 \pm 0.04$ & 0 & $2.22 \pm 0.22$ \\
\hline Fludioxonil & $0.32 \pm 0.02$ & 0 & 0 & 0 & 0 & $0.51 \pm 0.01$ \\
\hline Tebuconazole & $1.46 \pm 0.46$ & 0 & 0 & $0.10 \pm 0.00$ & 0 & $0.59 \pm 0.09$ \\
\hline
\end{tabular}

In our experiments, some correlation between quantity of $M$. nivale and $M$. majus DNA in seed and in stem base was found. Strong and significant correlation with both fungi species was determined in spring triticale and spring oats (Table 6). In spring wheat and spring triticale, seedling blight severity index strongly correlated with the DNA quantity of both pathogens in stem base.
The relationship between all parameters tested in spring barley was insignificant and correlation varied from medium to low. According to Turner et al. (2001), visual and PCR analyses on stems varied in relation to disease incidence or severity of symptoms and to the amount of pathogen DNA. Ramanauskiene et al. (2014) have previously reported that stem base and foot rot disease

Table 6. Correlation between quantity of Microdochium nivale and M. majus DNA in seeds and in stem bases and seedling blight severity index in different spring cereals in 2013-2015

\begin{tabular}{|c|c|c|}
\hline & $\begin{array}{l}\text { Quantity of } M \text {. nivale } \\
\text { in stem bases }\end{array}$ & $\begin{array}{l}\text { Quantity of } M . \text { majus } \\
\text { in stem bases }\end{array}$ \\
\hline \multicolumn{3}{|c|}{ Spring barley } \\
\hline Quantity of $M$. nivale in seeds & 0.685 & \\
\hline Quantity of $M$. majus in seeds & & 0.246 \\
\hline Seedling blight severity index & 0.285 & 0.520 \\
\hline \multicolumn{3}{|c|}{ Spring wheat } \\
\hline Quantity of $M$. nivale in seeds & -0.214 & \\
\hline Quantity of $M$. majus in seeds & & -0.261 \\
\hline Seedling blight severity index & $0.743^{*}$ & $0.760 *$ \\
\hline \multicolumn{3}{|c|}{ Spring triticale } \\
\hline Quantity of $M$. nivale in seeds & $0.968 * *$ & \\
\hline Quantity of $M$. majus in seeds & & $0.947 * *$ \\
\hline Seedling blight severity index & $0.877 * *$ & $0.751 *$ \\
\hline \multicolumn{3}{|c|}{ Spring oats } \\
\hline Quantity of $M$. nivale in seeds & $0.844^{*}$ & \\
\hline Quantity of $M$. majus in seeds & & $0.857^{*}$ \\
\hline Seedling blight severity index & -0.605 & -0.176 \\
\hline
\end{tabular}

* - significant at the 0.05 level (two-tailed), ** - significant at the 0.01 level (two-tailed)

incidence did not correlate with fungal DNA amounts from diseased stems. Other authors indicate significant relationship between visual infection symptoms and the incidence of $M$. nivale and $M$. majus on winter wheat (Matusinsky et al., 2008).

Results of our research showed that $M$. nivale and $M$. majus occur in spring cereals (wheat, barley, triticale and oats) and cause seedling blight. Control of seedling blight should be focused on complex pathogens and both Microdochium species as well.

\section{Conclusions}

1. Pathogens Microdochium nivale and M. majus were identified and quantified in the seed of spring barley, spring wheat, spring triticale and spring oats using a quantitative real-time polymerase chain reaction. The amount of $M$. nivale and $M$. majus DNA was the highest in the seeds of barley.

2. Real-time PCR confirmed the presence of both pathogens $M$. nivale and $M$. majus in the stem bases of seedlings of all cereal species tested; however, 
high variation between cereal species and years was established. In most cases, the quantity of $M$. nivale DNA was the lowest in the seedlings of oats, while that of $M$. majus - in barley seedlings compared to the other tested cereal species.

3. Stem base of the seedlings from the untreated seeds contained significantly higher amount of $M$. majus and $M$. nivale DNA compared to those of the seedlings from the fludioxonil-treated seeds, while tebuconazole showed inconsistent influence on the reduction of DNA amount of $M$. nivale and $M$. majus.

4. Positive correlation between quantity of Microdochium nivale and M. majus DNA in seed and in stem base of spring triticale and spring oats was determined. Seedling blight severity index significantly correlated with the quantity of DNA of both pathogens in stem base of spring wheat and spring triticale.

\section{Acknowledgements}

The paper presents research findings obtained through the long-term research programme "Harmful organisms in agro and forest ecosystems" implemented by Lithuanian Research Centre for Agriculture and Forestry.

Received 09082016

Accepted 31102016

\section{References}

Amein T., Omer Z., Welch C. 2007. Application and evaluation of Pseudomonas strains for biocontrol of wheat seedling blight. Crop protection, 27: 532-536 http://dx.doi.org/10.1016/j.cropro.2007.08.007

Bateman G. L., Edwards S. G., Marshall J., Morgan L. W., Nicholson P., Nuttall M., Parry D. W., Scrancher M., Turner A. S. 2000. Effects of cultivar and fungicides on stem-base pathogens, determined by quantitative PCR, and on diseases and yield of wheat. Annals of Applied Biology, 137: 213-221

http://dx.doi.org/10.1111/j.1744-7348.2000.tb00062.x

Cockerell V., Jacks M., McNeil M. 2009. Spring cereal seed infection with Microdochium nivale: cause for concern? BCPC Symposium Proceedings No. 83, p. 95-101

Dawson W. A. J. M., Bateman G. L. 2001. Fungal communities and disease symptoms on stem bases of wheat and barley and effects of seed treatments containing Fluquinconazole and Prochloraz. Journal of Phytopathology, 149: 665-671 http://dx.doi.org/10.1046/j.1439-0434.2001.00690.x

Doohan F. M., Brennan J., Cooke B. M. 2003. Influence of climatic factors on Fusarium species pathogenic to cereals. European Journal of Plant Pathology, 109 (7): 755-768 http://dx.doi.org/10.1023/A:1026090626994

Glynn N. C., Hare M. C., Parry D. W., Edwards S. G. 2005. Phylogenetic analysis of EF-1 alpha gene sequences from isolates of Microdochium nivale leads to elevation of varieties majus and nivale to species status. Mycological Research, 109: 872-880 http://dx.doi.org/10.1017/S0953756205003370

Glynn N. C., Hare M. C., Edwards S. G. 2008. Fungicide seed treatment efficacy against Microdochium nivale and M. majus in vitro and in vivo. Pest Management Science, 64 (8): 793-799 http://dx.doi.org/10.1002/ps.1558

Haigh I. M., Hare M. C. 2012. The effect of freezing temperatures on Microdochium majus and M. nivale seedling blight of winter wheat. International Journal of Agronomy, 2012: 1-5 http://dx.doi.org/10.1155/2012/359017
Haigh I. M., Jenkinson P., Hare M. C. 2009. The effect of a mixture of seed-borne Microdochium nivale var. majus and Microdochium nivale var. nivale infection on Fusarium seedling blight severity and subsequent colonisation and growth of winter wheat in pot experiments. Journal of Plant Pathology, 124 (1): 65-73 $\mathrm{http} / / / \mathrm{dx}$. doi.org/10.1007/s10658-008-9393-z

Hudec K. 2007. Pathogenicity of fungi associated with wheat and barley seedling emergence and fungicide efficacy of seed treatment. Biologia, 62 (3): 287-291 $\mathrm{http} / / / \mathrm{dx}$. doi.org/10.2478/s11756-007-0050-3

Hudec K., Muchova D. 2010. Influence of temperature and species origin on Fusarium spp. and Microdochium nivale pathogenicity to wheat seedlings. Plant Protection Science, $46(2): 59-65$

Humphreys J., Cooke B. M., Storey T. 1995. Effects of seed borne Microdochium nivale on establishment and grain yield of winter-sown wheat. Plant Varieties and Seeds, 8: $107-117$

Hwang F. S., Gossen B. D., Turnbull G. D., Chang K. F., Howard R. J., Thomas A. G. 2000. Effect of temperature, seeding date, fungicide treatment and inoculation with Fusarium avenaceum on seedling survival, root rot severity and yield of lentil. Canadian Journal of Plant Science, 80 (4): 899-907 http://dx.doi.org/10.4141/P99-177

Jørgensen L. N., Nielsen L. K., Nielsen B. J. 2012. Control of seedling blight in winter wheat by seed treatments - impact on emergence, crop stand, yield and deoxynivalenol. Acta Agriculturae Scandinavica, Section B: Soil and Plant Science, 62: 431-440 http://dx.doi.org/10.1080/09064710.2011.641028

Matusinsky P., Mikolasova R., Spitzer T., Klem K. 2008. Colonization of winter wheat stem bases by communities of pathogenic fungi. Cereal Research Communications, 36 (1): 77-88 http://dx.doi.org/10.1556/CRC.36.2008.1.8

McNeil M., Mackie J., Cockerell V. 2012. The effect of Microdochium nivale and M. majus on the establishment of spring barley and oats; evidence of host preference. Proceedings Crop Protection in Northern Britain, p. 187-192

Nicholson P., Turner A. S., Edwards S. G., Bateman G. L., Morgan L. W., Rappy D. W., Marshall J., Nuttall M. 2002. Development of stem base pathogens on different cultivars of winter wheat determined by quantitative PCR. European Journal of Plant Pathology, 108 (2): 163-177 http://dx.doi.org/10.1023/A:1015087311702

Nicolaisen M., Supronienė S., Nielsen L. K., Lazzaro I., Spliid N. H., Justesen A. F. 2009. Real-time PCR for quantification of eleven individual Fusarium species in cereals. Journal of Microbiological Methods, 76 (3): 234-240 http://dx.doi.org/10.1016/j.mimet.2008.10.016

Nielsen L. K., Jensen J. D., Nielsen G. C., Jensen J. E., Spliid N. H., Thomsen I. K., Justesen A. F., Collinge D. B., Jørgensen L. N. 2011. Fusarium head blight of cereals in Denmark: species complex and related mycotoxins. Phytopathology, 101 (8): 960-969 http://dx.doi.org/10.1094/PHYTO-07-10-0188

Nielsen L. K., Justensen A. F., Jensen J. D., Jørgensen L. N. 2013. Microdochium nivale and Microdochium majus in seed samples of Danish small grain cereals. Crop Protection, 43: 192-200 http://dx.doi.org/10.1016/j.cropro.2012.09.002

Ramanauskienė J., Gaurilčikienè I., Supronienè S., Ronis A., Česnulevičienè R. 2014. Evaluation of eyespot incidence and structure of Oculimacula spp. population in winter rye in Lithuania. Zemdirbyste-Agriculture. 101 (4): 425-430 http://dx.doi.org/10.13080/z-a.2014.101.054

Ren R., Yang X., Ray R. V. 2015. Comparative aggressiveness of Microdochium nivale and M. majus and evaluation of screening methods for Fusarium seedling blight resistance in wheat cultivars. European Journal of Plant Pathology, 141 (2): $281-294$

http://dx.doi.org/10.1007/s10658-014-0541-3 
Roháčik T., Hudec K. 2005. Influence of agro-environmental factors on Fusarium infestation and population structure in wheat kernels. Annals of Agricultural and Environmental Medicine, 12 (1): 39-45

Samuels G. J., Hallett I. C. 1983. Microdochium stoveri and Monographella stoveri new combinations for Fusarium stoveri and Micronectriella stoveri. Transactions of the British Mycological Society, 81 (3): 473-483 http://dx.doi.org/10.1016/S0007-1536(83)80115-6

Simpson D. R., Rezanoor H. N., Parry D. W., Nicholson P. 2000. Evidence for different host preference in Microdochium nivale var. majus and Microdochium nivale var. nivale. Plant Pathology, 49: 261-268 http://dx.doi.org/10.1046/j.1365-3059.2000.00453.x

Simpson D. R., Weston G. E., Turner J. A., Jennings P., Nicholson P. 2001. Differential control of head blight pathogens of wheat by fungicides and consequences for mycotoxin contamination of grain. European Journal of Plant Pathology, 107 (4): 421-431 http://dx.doi.org/10.1023/A:1011225817707

Suproniene S., Justensen A. F., Nicolaisen M., Mankeviciene A., Dabkevicius Z., Semaskiene R., Leistrumaite A. 2010. Distribution of trichothecene and zearalenone producing
Fusarium species in grain of different cereal species and cultivars grown under organic farming conditions in Lithuania. Annals of Agricultural and Environmental Medicine, 17 (1): 79-86

Špokauskiene O. 1991. Micromycetes of the cereals and their occurrence in Lithuania. 1. Micromycetes of the cereal roots and lower parts of stems. Ecology, 4: 9-21

Turner A. S., Nicholson P., Edwards S. G., Bateman G. L., Morgan L. W., Todd A. D., Parry D. W., Marshall J., Nuttall M. 2001. Evaluation of diagnostic and quantitative PCR for the identification and severity assessment of eyespot and sharp eyespot in winter wheat. Plant Pathology, 50: $463-469$ http://dx.doi.org/10.1046/j.1365-3059.2001.00592.x

Walker A. S., Auclair C., Gredt M., Leroux P. 2009. First occurrence of resistance to strobilurin fungicides in Microdochium nivale and Microdochium majus from French naturally infected wheat grains. Pest Management Science, 65 (8): 906-915 http://dx.doi.org/10.1002/ps.1772

Wollenweber H. W., Reinking O. A. 1935. Die Fusarien, ihre Beschreibung Schadwirkung und Bekämfung, 355 p. (in German)

ISSN 1392-3196 / e-ISSN 2335-8947

Zemdirbyste-Agriculture, vol. 103, No. 4 (2016), p. 363-368

DOI 10.13080/z-a.2016.103.046

\title{
Microdochium nivale ir M. majus - vasarinių javų daigu puvinių sukẻlèjai
}

\author{
A. Jonavičienė, S. Supronienė, R. Semaškienè \\ Lietuvos agrarinių ir miškų mokslų centro Žemdirbystès institutas
}

\section{Santrauka}

Vasarinių javų daigų puvinius dažniausiai sukelia Fusarium ssp. ir Bipolaris sorokiniana. Šis tyrimas patvirtino, kad ir Microdochium grybai, sudarę kompleksą su kitais patogenais, sukelia daigų puvinius. Microdochium nivale ir M. majus patogenai vasarinių miežių, vasarinių kviečiu, vasarinių kvietrugiu bei avižų sèklose ir daigu apatinès stiebo dalies pažaidose 2013-2015 m. buvo nustatyti taikant kiekybinę ir kokybinę realaus laiko polimerazès grandininę reakciją $(q P G R)$. Abi rūšys buvo aptiktos visų vasarinių augalų sėklose. Didžiausias kiekis $M$. nivale ir M. majus DNR buvo vasarinių miežių sėklose. Abu Microdochium patogenai nustatyti ant visų tirtų vasarinių javų daigu stiebo apatinès dalies, tačiau rasti kiekiai varijavo tarp augalu ir tyrimo metų. M. nivale DNR kiekis daugeliu atvejų buvo mažiausias avižų daiguose, o M. majus - miežių daiguose, lyginant su kitų tirtų rūšių augalais. Neapdorotų sẻklų daigų stiebo apatineje dalyje buvo nustatyti didesni kiekiai M. majus ir M. nivale DNR nei beicuotų fludioksonilu, o tebukonazolo įtaka mažinant $M$. nivale ir M. majus DNR kiekį buvo nenuosekli. Tyrimo duomenys parodè, $\operatorname{kad} M$. nivale ir M. majus pažeidžia vasarinių javų sẻklas ir sukelia daigų puvinius, todèl šių patogenų tyrimus būtina plèsti.

Reikšminiai žodžiai: daigų puviniai, fludijoksonilas, Microdochium majus, M. nivale, sèklų infekcija, tebukonazolas.

Please use the following format when citing the article:

Jonavičienė A., Supronienė S., Semaškienè R. Microdochium nivale and M. majus as causative agents of seedling blight in spring cereals. Zemdirbyste-Agriculture, 103 (4): 363-368 DOI 10.13080/z-a.2016.103.046 